\title{
An African Union without Muammar Gaddafi: Challenges and Prospects of Strong Arab-Black Africa Cooperation
}

\author{
Nwankwo T. Nwaezeigwe \\ Senior Research Fellow, Director \\ Institute of African Studies, University of Nigeria, Nsukka \\ nwankwo.nwaezeigwe@unn.edu.ng
}

DOI: 10.21608/MISJ.2021.160443

Received: 7-3-2021

Accepted: 6-4-2021

Published: 10-5-2021

\begin{abstract}
The uprising that eventually ousted Muammar Gaddafi was one political enigma that seems to have defied the imagination of most Africanist scholars. Many questions may arise, yet not all may find suitable answers. This paper however attempts to tackle some of these questions in the light of the respective roles played by the AU and NATO in the entire episode heralding the demise of the Libyan leader. First, could NATO's involvement in the Libyan conflict be a payback package for the Lockerbie Bombing and alleged Gaddafi's sponsorship of international terrorism? Secondly, why did the Africa Union, an organization whose conception and formation cannot be totally separated from visible efforts of Muammar Gaddaffi, stand aloof while NATO forces aided and abetted his destruction? Thirdly, given the subsequent trend of insecurity that greeted Gaddafi's exit from power both in Libya as represented by the warring factions, and globally as represented by the ISIS, could the objectives of Gaddafi's removable be said to have been me?
\end{abstract}

Key Words: Africa; Libya; African Union; Pan Africanism; Pan Arabism; Black Africans; Conflicts 


\section{Introduction}

Defined geographically, Libya is part of the Africa continent. Culturally and linguistically, it is generally defined as Arab, even though such Berber ethnic elements as the Amazigh and Tuareg are found. Strikingly enough, there appears to be increasing sense of irredentism among these Non-Arab sections of Libya since the demise of Muammar Gaddafi, as Edwin Lane of BBC News has reported in respect of the Amazigh. ${ }^{11}$

In religion, it is Islamic. In official circles, however, the country is defined as an Arab nation of North Africa. Thus like other North African Arab nations, Libya is a full member of both the League of Arab States and Africa Union. It thus holds a dual identity of an African and Arab nation respectively.

But then, given the above multifarious definition, where actually does one place Libya within the context of continental nationalism. In others, when all the above definitions are put on the scales of national identity, continental nationalism and, policy orientation of the former leader, could the Libya be authentically defined as an African or Arab nation?

The first approach towards the foregoing posers will be to look at the political heart-beat and policy orientation of the former Libyan leader, brother-leader Muammar Gaddafi, as he was fondly addressed by supporters. Writing from both the dimension of a researcher and a two-time official visitor to Libya on the invitation of the Libyan Government, the present writer will attempt to his blend his general knowledge as a scholar with his field experience as a visitor. Critically examined, to the average Libyan citizen, he is an Arab pure and simple without any pint of African blood in his veins and arteries. Although, they believe they are part of the Africa continent, but not as equals but a superior race, whose ancestral imperial rights over the Black Africans were truncated by the imperial European powers through colonialisms. The concept "we are all Africans" does not therefore in any way appeal to the mass of the Libyan people. To them, it was a slogan of the leadership which was only imposed on them by Muammar Gaddafi as part of policy of achieving a United States of Africa.

${ }^{1}$ Edwin Lane (2011) "After Gaddafi, Amazighi Demand Recognition," BBC New (Africa) 23, December, http://www.bbc.co.uk/news/world-africa-16289543, 1.

\section{Misriqiya}

International Journal of African-Egyptian Studies

Issue 2 (2021) 


\section{Gaddafi-Scion of Global Jihad}

The December 11, 1969 Constitution of Libya actually set out the fundamental basis of the Libyan government under Gaddafi. Part of the duties of the Socialist Arab State states as follows:

To denounce right-wing puritanistic ideas, and combat reactionarism in all its forms and shades; to enlighten the masses in the light of the precepts revealed in the Heavenly messages and the tradition of the Prophets. ${ }^{2}$

But it was in the section dealing with the objectives of the Third International that Gaddafi outlined the basis of his future conflict with the West. It reads thus:

After the First September Revolution, the Libyan Arab Republic enjoyed real freedom which was crowned by destruction of all foreign domination over the Libyan soil. Oil wealth was taken over from the monopolist companies to be put at the disposal of human beings everywhere. As a result of this freedom, the Libyan nation, equipped with human sense and tolerance derived from Islamic values, examined the plight of man in the west. It found the Western system based on exploitation, by individuals of the community where the rule $\mathrm{s}^{2}$ ays 'survival of the strongest', which has reduced society to a collection of broken families, torn apart by crime, vice and degeneration of all values....

It could therefore be interpreted in a way that given the above position, Gaddafi's confrontation with the West was inevitable. It is within this context that one could equally understand the reason for the West resoluteness on the removal of the Libyan strong man as well as Africa Union's aloofness in

\footnotetext{
${ }^{2}$ The First of September Revolution Achievements, 1969-74, (1974) Tripoli: General Administration for Information, Ministry of Information and Culture, 6.

${ }^{3}$ The First of September Revolution Achievements 1969-1974, 9.
}

\section{Misriqiya}

International Journal of African-Egyptian Studies

Issue 2 (2021) 
seeking an African solution to the conflict. Since Gaddafi did not only stop at theorization of his ideas, but went forward in subsequent years to match them with action.

To properly understand Muammar Gaddafi's political heart-beat, one must first be acquainted with the Three-Circle Foreign Policy objectives of the late Egyptian President, Gamal Abdel Nasser, from which it was obvious Gaddafi cloned his ideological principles. Nasser had propounded the three circles of the "African", "Islamic" and, "Arab", which were fundamentally aimed at reclaiming in Africa what is often described as the stolen Arab world supremacy by the Western powers. The African circle involved the total dewesternization and subsequent arabization of the continent, the Arab circle on the other hand involved the creation of a greater Arab nation strong enough to confront the west, while the third circle, Islam was to act as the ideological vehicle for achieving the two other objectives. ${ }^{4}$

Although, no one could easily deny the fact that Nasser evidently contributed in small measure to the progress of African liberation through overt support for those liberation movements that accepted to drink from the cup of his wine of Arab radical nationalism, his reputation among his fellow African leaders was greatly marred by his overt support for subversive elements in those African countries described as pro-West and reactionary.

The one striking question that readily comes to mind whenever the above three-circle policy is placed on the scale of international politics is, what manner of leadership did Nasser envision himself to offer when with one arm the same Egypt formed a United Arab Republic with Middle East Syria, and with another arm planning to form a United States of Africa with cooperation of the likes of Kwame Nkrumah of Ghana and Sekou Toure of Guinea.

The answer to the above question could easily be revealed from the heart of Nasser's Africa circle:

We cannot stand aloof from the terrible and terrifying battle now ragging in the heart of that continent between the five million whites and two hundred million Africans. We cannot stand aloof for one important and obvious reason- we ourselves are in Africa.

\footnotetext{
${ }^{4}$ Gamal Abdel Nasser (1955) The Philosophy of the Revolution Washington D.C., Public Affairs Press.
}

Misriqiya

International Journal of African-Egyptian Studies

Issue 2 (2021) 
Surely the people of Africa will continue to look to us- we who are the guardians of the continents northern gate- we who constitutes the connecting link between the continent and the outer world. We certainly cannot under any consideration, relinquish our responsibility to help spread the light of knowledge and civilization up to the very dept of the virgin jungles of the continent. ${ }^{5}$

To critical Africanists, the above tirade does not in any way contrast the European view and mission in Black Africa. Nasser did not in any manner claim to be African, but rather a civilizing agent for Black Africa in the same manner the European colonial adventurers would state their missions to Black Africa .. The question then is, what sort knowledge and civilization would the Arab world provide Black Africa in the context of the present age?

Scientifically and technologically, the Arabs have nothing new to offer other than what they themselves obtained from the West. Spiritually, the European Christianity provides an air of freedom for liberalism, accommodation, tolerance and innovation. While politically, the concept of participatory mass form of government defined as Western democracy cannot thrive under a surging tide of Islamic re-assertion.

A critical examination of both internal and external policies of Brother Leader Muammar Gaddafi reveals a wholesome adoption of Nasser's views and mission in Black Africa, although with deeper exploration in his implementation approach. For instance, he meticulously expanded Nasser's three circles to seven. Titled "Support of the Peoples' Causes", and placed under the section dealing with "Political Action" in the Third International Theory, it includes "the National Scale", "the International Scale", "the African Scale", "the Islamic Scale", "the Mediterranean and European Scale", "the Third World and Non-Aligned Countries Scale", and "the Revolutionary use of Oil Weapon". ${ }^{6}$

${ }^{5}$ Nasser, The Philosophy of the Revolution, 69.

${ }^{6}$ The First of September Revolution Achievements, 17-25.

\section{Misriqiya}

International Journal of African-Egyptian Studies

Issue 2 (2021) 


\section{Social Contradictions of Gaddafi's Libya--- A Personal Account}

Before the present writer visited Libya, he had the impression of a country where all Africans-: both Black and Arab were treated as equals given the over-dramatized nature of Gaddafi's Pan-African project and cloned Africanity. There was also the impression of an all-Arab indigenous Libya. Furthermore, given the personal anti-West and anti-Zionist tirades of the Libyan Leader, one did not expect any evidence of the so-called Western neocolonialism, particularly as directly connected with the United States of America and the State of Israel.

The present author was however shocked when his allowances from the Libyan government were paid in US dollars, which was also freely used side by side with the Libyan dinar as the second currency. It was also further discovered that a number of the fruits served in hotels and as well sold in markets, mainly citrus and apple transited to Libya from the State of Israel. It was at this stage that the present writer decided to explore the inner city of Tripoli, even against popular advice by his colleagues not to, because of the prevailing anti-guest security network. Consequently the old city of Medina, a slum suburb of the magnificent capital city of Tripoli was chosen as the primary focus of the trip.

The choice of Medina is obvious because it represents what is usually referred to as the gheto in America. In other words, this was where the underprivileged represented mainly by the poor and low-class including the unemployed, as well as most of the immigrants from Black African Countries, mainly Nigeria, Mali, Niger and Ghana cluster around to seek alternative means of survival on mother-earths. This was equally where all forms of crime were said to be brooded and hatched.

Adorned in his traditional Igbo kaftan with a red-fez cap to match, it was not long before a group of Nigerian immigrants clustered around him. Through these people he got in contact with some isolated free Libyans who spoke the English language with enthusiastic difficulties. Although equally useful in this respect was a Black Libyan of Tuareg extraction, a lecturer with University of Benghazi who, although initially appearing to be sinister and obstructive in attitude, was later forced to let out some vital information.

Misriqiya

International Journal of African-Egyptian Studies

Issue 2 (2021) 
One striking feature of the Libyan society which is credited to the fundamental tenets of Al Gaddafi's Peoples Socialist State was the high degree of social welfare, housing and employment for the average Libyan. The society was also characterized by a high degree of moral rectitude and low crime rate. Women were rarely married without their virginity being preserved. But one striking contrast to this enforced morality was the prevalence of prostitution in Libyan society under Muammar Gaddafi.

What this meant was that most unmarried young men had to shift their emotional flag-ship to the prowling foreign prostitutes mainly Black Africans, Philippinos and Arabs mostly from Morocco, Tunisia, Sudan and Egypt. A number married Libyans equally patronized the prostitutes mainly because they could not afford to marry additional wives even if they had decided to in accordance with Islamic injunctions. This appeared to have been made conditionally difficult by the restricted and tailor-guided nature of the Libyan society, particularly in such areas as housing, income distribution and strict pro-Gaddafi security network.

The 1969 Constitutional declaration had defined Libya as a Socialist State in which in which "public ownership is the basis for the development of the society and for the realization of sufficiency in production" ${ }^{77}$ In other words, private enterprise and ownership of property were restricted. However, it was only in the rural desert areas that polygamy appeared to have been practised without much restriction. Elsewhere in Urban centres, polygamy remained an exclusive preserve of the higher-income class who were mostly found within the Government circles and had enough resources to carter for extra women.

Socially and politically however, Libya under Muammar Gaddafi was still divided along racial lines. The Berber group represented by the Tuareg and Amazigh were rarely entrusted with important State positions. Most of them worked in security agencies in low ranking status, others as official drivers and similar low-income services. In addition, a number of nationals of some Black African nations which equally included naturalized immigrants from

\section{${ }^{7}$ The First of September Revolution Achievements, 3}

\section{Misriqiya}

International Journal of African-Egyptian Studies

Issue 2 (2021) 
Sudan, Niger, Chad and Nigeria were also enlisted into the Libyan Security forces to service the Muammar Gaddafi imperial ambition.

Often the Libyan strongman used some of these Black Security officials to show-case his often orchestrated Africanity in official functions, particularly in African related conferences. That is notwithstanding the fact that his most trusted personal guards consisted of young women presumed to be Virgins.

During the Second Conference for the Forum of kings, Sultans, Princes, Sheikhs and Mayors of Africa, held in Tripoli in September 2010, the author witnessed on two occasions - first during interactions with the leader, and second, during a cocktail party, the frequency with which these Black guards were changed.

It was noticed that rarely did each guard stay on his position for more than twenty minutes. It was therefore obvious that even though Blacks formed part of the Libyan Security Agencies, they featured within the low-ranking stratum with minimal trust.

On the whole, the core of Libyan security forces and civil officials remained not just Arab, but Bedouin. In other words, you must be an Arab desert tribesman to be entrusted with sensitive or high-ranking position. It is also important to note that no person of Berber origin had ever been found qualified enough to be an Ambassador, Minister, Director of a Government Agency or Commander of any of the Security Agencies. The average Arab Libyan, especially the educated one often habitually found it not just difficult but degrading to take instructions from his non-Arab co-citizen.

Even a closer interaction with, or an attempt to get vital information about the nation by visitors, was treated with suspicious scorn Libyan officials. The present writer was further pissed off when even the Black Tuareg scholar, in imitation of his Arab masters first attempted to be evasively arrogant, before he was tactically reminded of his Black skin.

\section{A Pan-Africanism in Contradiction}

At the level of international politics, this Arab imperial concept of superiority over the Black Africans took the form of a Black garb upon a white skin. Like a hunter dressing in a wild animal skin in other to deceive the animals, Gaddafi believed that Abdel Nasser's failure in spreading the vile wind of Arab neocolonialism in Black Africa arose out of his inability to claim African

\section{Misriqiya}

International Journal of African-Egyptian Studies

Issue 2 (2021) 
descent. For Gaddafi therefore, he must claim African descent in order to conquer the Black African mind.

But to what extent could the Libyan leader be described as an African stands to be proved by the direction and feature of his Africa policy. As earlier pointed out, the core features of his foreign policy were centered on a scripted version of Abdel Nasser's three circle-policy objectives- the Arab, African and Islamic circles. He only went further to expand the dimension of his objectives on lines hitherto not mentioned by Nasser.

Thus like Abdel Nasser, even though Islam never formed the basis of the nation's administrative framework, it however acted as the major instrument for the pursuit of the other two objectives. Like Abdel Nasser also who used the Muslim Brotherhood to come to power and later proscribed it, Muammar Gaddafi rode to power through the support of the Sannusiyya Brotherhood and later outlawed it.

In place of Abdel Nasser's Philosophy of the Revolution, he equally published the Green Book. ${ }^{8}$ Although unlike Nasser's Philosophy of the Revolution, in which the subject of Islam appeared prominent, the Green Book down-played Islam as the main ideological basis of his Arab People's socialism. This was evidently in stark contrast to what was contained in The Third International Theory in which Islam featured prominently. ${ }^{9}$ However, both Arab nationalists agreed that Black Africa was backward and thus needed to be placed on proper modern civilized state within the precept of the Arab mind.

In line with Abdel Nasser's thinking therefore, Muammar Gaddafi stated in his Green Book concerning the Black people thus:

The latest age of slavery has been the enslavement of Blacks by White people. The memory of this age will persist in the thinking of Black people until they have vindicated themselves. This tragic and historic event, the resulting bitter feeling, and the yearning for the vindication of a whole race, constitute a psychological motivation of Black people to vengeance and triumph that cannot be disregarded.... Black people are now in a very backward social

\footnotetext{
${ }^{8}$ Muammar Al Qaddafi (1991) The Green Book, Tripoli: The New Rose et Youseff Printing Press.

${ }^{9}$ The First of September Revolution Achievements, 9
}

Mistiqiya

International Journal of African-Egyptian Studies

Issue 2 (2021) 
situation, but such backwardness works to bring about their numerical superiority.... ${ }^{10}$

Thus, to Gaddafi, the assumed backwardness of the Black man and his uncontrolled population explosion must be utilized to rent vengeance against his erstwhile White colonial masters. Like Abdel Nasser therefore, Gaddafi sees himself in competition with the West for the imperial control of Black Africa. This was no doubt the thrust of his African Scale policy, in which he earlier stated that:

... the Libyan Arab Republic has adopted a series of effective moves aimed at liquidating Zionist influence in the Africa continent. The results of such moves are crystal clear in the positive response adopted by the Africa Continent in favour of the Arabs during the Ramadan war; the response took the shape of breaking diplomatic relations with the Zionist enemy. ${ }^{11}$

This accounted for dramatic assumption of cloned African identity, which consequently led to his enormous commitment of financial resources in support of dissident groups in those African nations whose leaders overtly opposed his imperial Arab designs, formation of numerous internationallybased non-governmental organizations as instruments of opposition against their respective governments, and above all sacrificially working for the emergence of the African Union (AU).

In all these schemes, conversion to Islam formed a major aspect of operation. The aspect of Gaddafi's policy dealing with political action was emphatic on the role of Islam in his foreign policy objectives:

In reshaping their way of life, in accordance with the spirit of the noble Islamic law, the Libyan Arab Republic calls for fraternity and solidarity among all Muslims, as it urges to shoulder

${ }^{10}$ Al Qaddafi, The Green Book, 96

${ }^{11}$ The First of September Revolution Achievements, 22

\section{Misriqiya}

International Journal of African-Egyptian Studies

Issue 2 (2021) 
responsibility of waging a holy war in the service of God and of the unification of Muslims. ${ }^{12}$

The present writer was astonished to discover that conversion to Islam formed a major feature of all the Gaddafi- sponsored non-governmental organizations and conferences. For instance, during the Second Conference of the Forum of kings, Sultans, Princes, Sheikhs and Mayors of Africa, which the present writer attended, a number of Black African delegates from predominantly Christian countries, like Ghana, Cote d'Ivoire, Cameroon, Congo Democratic Republic, and Central African Republic, among others, were made to publicly denounce Christianity and convert to Islam on promise of financial rewards.

The same also happened during the Sixth Conference of the Social Popular League of Great Sahara Tribes, which the present author also, attended penultimate the outbreak of the Libyan conflict. As part of the program of the events, the present writer, a Christian Nigerian delegate to the Conference was forced by the circumstance of the moment to join the Libyan leader in the Jumat prayer for the Birthday celebration of Prophet Muhammad, which was held at the Islamic University, Tripoli. The writer could also remember very vividly of being subtly asked by one of the officials if his ethnic group the Igbo of Nigeria, are indeed of Jewish Origins.

It is therefore clear that Gaddafi's main objective for the formation of these organizations includes first, the gradual islamization of Christian Black Africa, and secondly as a source of popular opposition to Western influence among the people. The latter objective is in fact the main focus of the Popular Social League of the Great Sahara Tribes, formed in Timbuktu, Mali Republic in 2006. This was primarily an Islamic organization that tried to unite the Islamic nations of Africa and Arab World under the leadership of the Libyan leader.

The character of this organization was made vivid in an opening speech during its formation in Timbuktu, Mali thus:

On 12 Rabie A-Awal 1374) (2006) in Tombouctou City, Mali, the Tombouctou Pact, the Pact of the Social Peoples Association of

${ }^{12}$ The First of September Revolution Achievements, 23

\section{Misriqiya}

International Journal of African-Egyptian Studies

Issue 2 (2021) 
Sahara Tribes, was celebrated in the leader of the Revolution's meeting, in his place of residence in Tombouctou with the kings, Sultans, Sheikhs, and Chiefs of Sahara tribes from Senegal and Mauritania in the west to Irag in the east passing through North Africa, the Nile Valley, the Syrian Desert, the Arabian Peninsula, the African Horn, as well as Sudan, Chad, and Niger whose historical and big home is the Sahara. The celebration was attended by a number of Heads of Islamic Institutions, Sheikhs of Sufi trends and members of the World Islamic Peoples leadership.... In that meeting the leader of the Revolution, the leader of the World Islamic People's leadership led thousands of Muslims from around the world in prayers of Maghreb (sunset) and Ishaa (evening). ${ }^{13}$

Its fundamental objectives were clearly laid out in paragraphs five and eight, article 3, of the first chapter of its Statute. Paragraph five states succinctly as one of the organization's objectives, the defense of "the Great Sahara against any danger", while paragraph eight in like manner talks of "combating imported colonialist culture". ${ }^{14}$ The question which arises from these two objectives then is what better danger other than Western influence, and what imported colonialist culture other than Christianity could be threatening the said Great Sahara Tribes?

This question was however expressly answered in the historic Tombouctou Pact of the Social People's Association of Sahara Tribes. In its innermost conviction, the fact was direct to the point:

On this great day, these tribes stress that they may even face death in order to achieve the security, independence, and stability of the Sahara. They declare that they will not forsake a grain of sand of the Sahara, that Sahara tribes will have no life without freedom,

13 The Popular Social League of the Great Sahara Tribes (2006), Celebration of the Establishment of the Social People's Association of the Sahara Tribes, Tombouctou: n.p, 8

${ }^{14}$ The Popular Social League of the Great Sahara Tribes (n. d.) The Statute of the Social Popular League of the Tribes of the Great Sahara, n. p., 29

Mistiqiya

International Journal of African-Egyptian Studies

Issue 2 (2021) 
and that the freedom of the Sahara and its people is indivisible. We declare that we shall be enemies of whoever is against us, and we will be at peace with whoever is at peace with us. We declare that all Sahara tribes will confront any new attempt made by any party to threaten the security, stability independence, and freedom of the Sahara and its people. The Sahara sands, stones, and air will turn into scorching fire against whoever will be occupying the Sahara or threatening its security, freedom, independence, or stability. ${ }^{15}$

There is therefore no gainsaying the fact that the Popular Social League of the Great Sahara Tribes in which Gaddafi was described as the leader of the World's Islamic leadership, was one of the international instruments of his anti-West campaign among the Arab and African Muslim grassroots.

On the other hand, the Forum of Kings, Sultans, Princes, Sheikhs and Mayors of Africa which was formed in August 2008, became the main vehicle of his Africa-Circle objectives. Its fundamental objectives were subsumed in the first two paragraphs of Article Four of its Statute:

To contribute in the achievement of the African Union moved by the fact that true unity is the one realized by the will of the masses. To support African peoples in relation to selfdetermination.... ${ }^{16}$

This initiative coming at the time the Libyan leader was the Chairman of the Africa Union, he used the occasion to fulfill his utopian imperial objectives, if not in deed but in words, when he convinced the gathering local African royalties to crown him the king of Traditional kings of Afria. ${ }^{17}$ As the king of Traditional kings of Africa, the Libyan leader received annual homage and tributes in the form of gifts from these kings and other royalties. Interestingly

\footnotetext{
${ }^{15}$ Celebration of the Establishment of the Social Popular_Association of Sahara Tribes, 22

${ }^{16}$ Statute of the Forum of Kings, Sultans Princes, Sheikhs and Mayors of Africa, 28

${ }^{17}$ The Foundation Conference of the General Forum of Kings, Sultans, Princes, Sheiks and Mayors of Africa Benghazi, August $26^{\text {th }}-$ September $2^{\text {nd }}, 2008,1$
}

\section{Misriqiya}

International Journal of African-Egyptian Studies

Issue 2 (2021) 
enough, none of these kings and Princes were influential enough to initiate in any form, pro-Gaddafi policies in their respective countries, like the present author, who attended on the capacity of a Traditional Nigerian Chief of Igbo ethnic extraction.

In fact, in obedience to Nigerian delegates' resolve to pay the traditional homage to the Libyan leader, the author was made to pay the sums of fifteen thousand naira ( $\$ 15,000)$, about one hundred US dollars in contribution for some traditional Nigerian articles of gift for the leader.

However, while the first objective could be said to be utopian in projection, it did not appear to so with the second objective, which dealt with support for insurgency among African nations. This objective in fact clearly accounted for the huge amount of support the Libyan leader rendered to dissident groups in many African countries.

In fact, in the course of the conference, the present writer was surprised to learn that one of the major militant leaders in Nigeria's Niger Delta region, Mujaheed Asari Dokubo, had Gaddafi as his god-father, through whom he acquired the needed material for his activities. It was also learnt that Dokubo's conversion to Islam in the course of the conflict was the trump-card presented by Gaddafi for his support.

It is evident that with the enormous energy and financial resources the Libyan leader had periodically committed to the support of dissident groups in Arab and African countries, one should have taken him as the face behind the mask of the Arab Spring. This assumption came in the face of the massive celebrations the Libyan leader had with the conference delegates over the successes of the Tunisian and Egyptian uprisings. But as Al-Madini, the Secretary-General of al-Fatah Revolutionary Committee prophetically put it, the fear of these revolutions being hijacked by imperialists could not be ruled out. Prophetically so it came to be in Libya with the subsequent demise of the Libyan leader.

The West's resolute resolve to remove the Libyan leader from power was obvious. Since the demise of the Iraqi strongman Saddam Hussein, the Libyan leader remained the main fire-work for international terrorism and related antiWestern activities among the Arab and Black African nations. His overt celebration as hero, the released Libyan terrorist involved in the Lockerbie

\section{Misriqiya}

International Journal of African-Egyptian Studies

Issue 2 (2021) 
bombing was evidence of an unrepentant god-father of international terrorism. To the West therefore, the battle for Libya was a pay-back time for the man who once seemed to be invincibly clouded with the massive support of the international Muslim community.

On the part of the Arab nations, already jolted by the whirl-wind of widespread anti-Government uprisings, with many sitting on shaky seats of power, the Libyan intervention by the West became a sacrificial albatross for their individual survivals. Moreover, most of these nations were not unaware of the Libyan leader's role as the chief supporter of dissident groups in their countries just in the same manner Nasser was viewed.

To the Black African nations, the Libyan conflict, far from being an African problem, was not only an internal Libyan affair, but a part of the enveloping wind of political change in Arab World. If the African Union could not intervene effectively in the Sudanese conflict to save the Black Africans of the South and Darfur from the obvious Arab racist machine miscalled the Sudanese Government, is it in a conflict that concerned two groups of Arab brothers fighting for supremacy that the unexpected would have taken place?

In fact the so-called Africa Union (AU) Libya Panel was a political farce, because they knew it was bound to fail. The AU had initiated a road-map which included "cease-fire" and "reforms necessary for the elimination of the causes of the current crisis," which was followed with President Zuma's visit to the Libyan leader. ${ }^{18}$ The effort was bound to fail because if the AU was serious about resolving the crisis, such action should have been taken long before the UN no-fly zone resolution. It was obvious that both the Africa Union and the West, including of cause the Arab League were in agreement that Muammar Gaddafi should go.

But beyond his role as the god-father of International terrorism and insurgency, the Libyan leader had no doubt created indelible track records in Black Africa-Arab relations, even though selfishly tailored. He invested enormously in the formation of the Africa Union in which he was more at home than in Arab League. If Libya is painted today in black racial color to the disappointment of the present post-Gaddafi regime, it was the result of

18“Zuma Slams Nato Libya Operation as AU Panel Meets"
(2011)RFI,http://www.english.rfi.fr/node/97793/1/26/20125:20pm
Misriqiya

International Journal of African-Egyptian Studies

Issue 2 (2021) 
Gaddafi's effort to become truly African, if not in color, but in political orientation. There was no doubt that Muammar Gaddafi was truly a TranSaharan Pan-Africanist, the type Professor Ali Mazrui calls "Ideological Afrabians." $" 19$

\section{Conclusion}

There is no doubt that the demise of Gaddafi brought to an end one of the most colorful but vociferous ideologues and ecstatic imperial adventurers after the likes of Kwame Nkrumah and Gamal Abdel Nasser. There is also no doubt that it was his theatrical roles as an exporter of Islamic fundamentalism and supporter of dissident groups woven in untenable obsession for power that widened the gap between him and his fellow African Union leaders, much in the same way it did with the his Arab League counterparts. Otherwise, how could somebody who tirelessly worked for the actualization of the dream of Africa Union, as well as fanatically pursued the causes of Arabism and Islam be left in the ditch like a political orphan by the same institutions at the time of his need? The reason is obvious: it is in fact supposed by the pay-back theory that the Libyan leader experienced equally the taste of the same vile dissident fruits he once exported to other countries.

But one question which readily comes to mind following the demise of Muammar Gaddafi is will Black Africa's relations with Libya ever be the same after Gaddafi? In other words, could the exit of Muammar Gaddafi herald the end of Tran-Saharan Pan-Africanism? This question appears obvious in the light of a policy statement credited to the embattled NTC Libyan Foreign Minister, Achour Ben khayal, in which he said that the new Libya will definitely play a different role from what obtained during the Gaddafi era. ${ }^{20}$ The question which thus arises from the post-Gaddafi conflicts occasioned by the many warring factions and coupled with the current spate of organized hostilities against Black African immigrant workers in the country is what is

${ }^{19}$ Ali A. Mazrui et al (2009) Africa's Islamic Experience: history, culture, and politics, New Delhi: Steeling Publishers, 110

20، Ping Defends Africa Union Mediation in Libya" RFI http://www.english.rfi.fr/africa/20120126-ping-defends-africa-union,i/26/2012,5:19pm.

\section{Misriqiya}

International Journal of African-Egyptian Studies

Issue 2 (2021) 
the prospect of enduring Black Africa-Arab relations in post-Gaddafi Libya? Does the exit of Muammar Gaddafi mean the end to Pan-African spirit and the rise of Pan Arab ideological supremacy in Libya?

\section{References}

Lane, Edwin (2011) "After Gaddafi, Amazighi Demand Recognition," $B B C$ News (Africa) 23, December, http://www.bbc.co.uk/news/world-africa16289543

Mazrui et al Ali A. (2009) Africa's Islamic Experience: history, culture, and politics, New Delhi: Steeling Publishers

Nasser, Nasser Gamal Abdel (1955) The Philosophy of the Revolution Washington

Qaddafi, Muammar Al (1991) The Green Book, Tripoli: The New Rose et Youseff Printing Press.

Social People's Association for the Sahara Tribes (2008) The $3^{\text {rd }}$ Comprehensive Historical Forum of the Sahara Tribes, Kampala CityUganda

Forum of Kings, Sultans Princes, Sheikhs and Mayors of Africa (2009) Statute of the Forum, Tripoli: Falak39

The First of September Revolution Achievements, 1969-74, (1974) Tripoli: General Administration for Information, Ministry of Information and Culture Printing Press

The Popular Social League of the Great Sahara Tribes (2007) Celebration of the Establishment of the Social People's Association of the Sahara Tribes, Tombouctou: Saharakobra

The Popular Social League of the Great Sahara Tribes (2006) The Statute of the Social Popular League of the Tribes of the Great Sahara, Tombouktou: Saharakobra

\section{Mistiqiya}

International Journal of African-Egyptian Studies

Issue 2 (2021) 
The Popular Social League of the Great Sahara Tribes (2009) Fourth Forum of the League Nouakchott: Saharakobra

The General Forum of Arab and African Non-Governmental Organizations (2008) The Foundation Conference August $26^{\text {th }}-$ September $2^{\text {nd }}$ Benghazi: Falak39

"Zuma Slams Nato Libya Operation as AU Panel Meets" (2011)RFI,http://www.english.rfi.fr/node/97793/1/26/20125:20pm.

"Ping Defends Africa Union Mediation in Libya" RFI http://www.english.rfi.fr/africa/20120126-ping-defends-africaunion, i/26/2012,5:19pm. 